\title{
PERBEDAAN PERSENTASE BUSA LERAK PADA BATA BETON RINGAN FOAM DI TINJAU DARI SIFAT FISIK DAN MEKANIK
}

\author{
Eryan Nuzuliana Cahyanto ${ }^{1}$, Sri Sumarni ${ }^{2}$, Chundakus Habsya ${ }^{2}$ \\ Email : eryannuzuliana@gmail.com
}

\begin{abstract}
Abstrak
Tujuan penelitian adalah : (1) Menyelidiki perbedaan kuat tekan bata beton ringan foam dengan perbandingan semen dan pasir serta kandungan foam yang berbeda, (2) Menyelidiki perbedaan berat jenis bata beton ringan foam dengan perbandingan semen dan pasir serta kandungan foam yang berbeda, (3) Menyelidiki perbedaan daya serap air bata beton ringan foam dengan perbandingan semen dan pasir serta kandungan foam yang berbeda, (4) Menyelidiki berapa nilai maksimal kuat tekan bata beton ringan foam dengan perbandingan semen dan pasir serta kandungan foam yang berbeda. Penelitian ini menggunakan metode kuantitatif experimen dan teknik analisis data menggunakan analisis T-Test. Perbandingan bata beton ringan foam menggunakan semen dan pasir 1:1, 1:2 dan foam lerak $30 \%$ dan $40 \%$ dari volume mortar. Variabel yang membedakan dalam penelitian adalah (1) variabel terikat: kuat tekan, berat jenis dan daya serap air bata beton ringan foam, (2) variabel bebas: variasi busa lerak 30\% dan $40 \%$ dengan perbandingan semen dan pasir 1:1 dan 1:2. Hasil penelitian antara lain, (1) Kuat tekan bata beton ringan foam dengan persentase busa lerak $30 \%$ lebih tinggi dari pada busa lerak $40 \%$, perbedaan kuat tekan pada campuran $1 \mathrm{pc}: 1 \mathrm{ps}$ sebesar $5,8658 \mathrm{MPa}(75,34 \%)$ dan $1 \mathrm{pc}: 2 \mathrm{ps}$ sebesar 1,4648 MPa (57,14 \%), (2) Berat jenis bata beton ringan foam dengan persentase busa lerak $30 \%$ lebih tinggi dari pada busa lerak $40 \%$, perbedaan berat jenis pada campuran 1pc:1ps sebesar $268 \mathrm{~kg} / \mathrm{m}^{3}(16 \%)$ dan 1pc:2ps sebesar $292 \mathrm{~kg} / \mathrm{m}^{3}(18,91 \%)$, (3) Daya serap air bata beton ringan foam dengan persentase busa lerak $30 \%$ lebih tinggi dari pada busa lerak $40 \%$, perbedaan daya serap air pada campuran $1 \mathrm{pc}: 1 \mathrm{ps}$ sebesar 4,676 \% dan 1pc:2ps sebesar 2,849 \%, (4) Kuat tekan maksimal sebesar 7,7856 MPa pada persentase busa lerak sebesar $30 \%$ dengan perbandingan $1 \mathrm{pc}: 1 \mathrm{ps}$.
\end{abstract}

Kata Kunci : busa lerak, bata beton ringan foam, kuat tekan, berat jenis, daya serap air.

\footnotetext{
${ }^{1}$ Mahasiswa Program Studi Pendidikan Teknik Bangunan FKIP UNS

${ }^{2}$ Pengajar Program Studi Pendidikan Teknik Bangunan FKIP UNS
} 


\title{
DIFFERENCE OF FLAT FOAM PERCENTAGE IN LIGHT WEIGHT CONCRETE FOAM IN THE REVIEW OF PHYSICAL AND MECHANICAL PROPERTIES Eryan Nuzuliana Cahyanto ${ }^{1}$, Sri Sumarni ${ }^{2}$, Chundakus Habsya ${ }^{2}$
}

Email : eryannuzuliana@gmail.com

\begin{abstract}
The objectives of the study are (1) Investigate the difference in compressive strength of lightweight foam concrete brick with a comparison of cement/sand and foam content different, (2) Investigate differences in the density of foam lightweight concrete bricks with a comparison of cement/sand and foam content different, (3) Investigate the difference in absorption of foam lightweight concrete bricks with a comparison of cement/sand and foam content different, (4) Investigate the maximum value of foam lightweight concrete brick compressive strength with a comparison of cement/sand and foam content different. This study uses quantitative experiment method and data analysis technique using T-Test analysis. Comparison of lightweight foam concrete bricks using 1: 1, 1: 2 cement and sand and lerac foam 30\% and 40\% of the volume mortar. The distinguish variables in the study are (1) the dependent variable: compressive strength, density and water absorbability of lightweight concrete bricks foam, (2) independent variable : variation of lerak foam $30 \%$ and $40 \%$ with a ratio of cement and sand $1: 1$ and 1: 2. Research results include, (1) Compressive strength of lightweight foam concrete brick with the percentage of lerak foam 30\% higher than lerak foam $40 \%$, the difference in compressive strength on the mixture of $1 p c$ : $1 p s$ is $5.8658 \mathrm{MPa}(75.34 \%)$ and $1 p c: 2 p s$ of $1.4648 \mathrm{MPa}(57.14 \%)$, (2) The weight of lightweight foam concrete brick with the percentage of lerak foam is 30\% higher than the 40\% lerak foam, the difference in density in the 1pc: 1ps mixture is $268 \mathrm{~kg} / \mathrm{m3}$ (16\%) and 1pc: $2 p s$ of $292 \mathrm{~kg} / \mathrm{m3}$ (18 91\%), (3) Water absorption of foam lightweight concrete bricks with a percentage of lerak foam $30 \%$ higher than lerak foam $40 \%$, difference in water absorption in a mixture of 1pc: $1 p s$ of $4.676 \%$ and 1pc: $2 p s$ of $2.849 \%$, (4) The maximum compressive strength is $7.7856 \mathrm{MPa}$ in the percentage of lerak foam of $30 \%$ with a ratio of $1 \mathrm{pc}: 1 \mathrm{ps}$.
\end{abstract}

Keywords : lerak foam, lightweight concrete brick foam, compressive strength, density, water absorption.

\footnotetext{
${ }^{1}$ Student of Civil Engineering of Education FKIP UNS

${ }^{2}$ Lecturer of Civil Engineering of Education FKIP UNS
} 


\section{PENDAHULUAN}

Perkembangan dunia konstruksi di Indonesia saat ini mengalami persaingan yang sangat ketat. Perusahaan-perusahaan konstruksi dituntut untuk mampu meningkatkan sumber daya yang dimilikinya, tidak hanya pada sumber daya manusianya tetapi juga pada sumber daya penunjang lainnya. Dibutuhkan berbagai macam inovasi, baik dalam pengadaan material, proses pembuatan maupun pada tahap pelaksanakan agar dapat berjalan seimbang dengan perkembangan konstruksi tersebut.

Beton merupakan salah satu bahan yang sering dimanfaatkan dalam proyek konstruksi skala besar maupun kecil. Salah satu diantara macam beton tersebut adalah beton ringan, dimana beton jenis ini sama dengan beton biasa yang diberi bahan tambah yang mampu membentuk gelembung udara di dalam beton. Beton semacam ini mempunyai banyak pori sehingga berat jenisnya lebih rendah daripada beton biasa. Menurut SNI-03-2847-2002, beton ringan adalah beton yang mengandung agregat ringan dan mempunyai berat satuan dengan densitas lebih kecil dari $1900 \mathrm{~kg} / \mathrm{m}^{3}$.

Menurut Tjokrodimuljo (1996) beton ringan dapat dibuat dengan beberapa cara yaitu pertama dengan membuat gelembung-gelembung gas/udara dalam adukan semen sehingga terjadi banyak pori udara dalam beton. Kedua, penggunaan agregat ringan, misalnya tanah liat, batu apung atau fly ash untuk adukan semen sehingga beton yang dihasilkan lebih ringan dari beton normal. Ketiga dengan membuat beton tanpa agregat halus atau sering disebut beton non pasir.

Bata beton ringan foam merupakan beton yang dibuat dengan menambahkan foam agent (cairan busa) kedalam campuran beton. Foam agent akan menghasilkan bata yang lebih ringan dari bata konvensional. Hal ini disebabkan foam akan melipatgandakan volume hingga dua kali lipat, yang mana rongga-rongga udara di dalam adukan terisi oleh gelembunggelembung dari foam. Foam agent sendiri memiliki dua jenis yaitu jenis sintetik dan jenis organik. Jenis sintetik ini merupakan produk kimia murni dan jenis organik berbasis protein hewani (Khalid, 2011).

Salah satu bahan alternatif
pengganti foam agent untuk dikembangkan fungsinya adalah tanaman lerak (sapindus rarak). Tanaman lerak dikenal sebagai bahan deterjen tradisional karena tanaman ini dapat menghasilkan busa. Kulit batang dapat digunakan sebagai pembersih rambut, buahnya yang bulat dapat dimanfaatkan sebagai pengganti sabun untuk mencuci berbagai macam kain. Keunikan dan kelebihan lerak dibandingkan dengan sabun atau deterjen kimia adalah lebih ekologis dan ekonomis. Limbah lerak dapat diuraikan oleh alam dan tingkat pencemarannya hampir tidak ada. Kandungan racun biji lerak dapat digunakan sebagai insektisida dan air bekas cucian bisa diurai mikroorganisme sehingga tidak mencemari lingkungan (Rosyidah, 2013).

Menurut Andriani (2016) pembuatan beton ringan dengan material penyusunnya semen, kapur, air dan foam organik yang dihasilkan dari ekstrak buah lerak menggunakan perbandingan semen dan kapur 1:4. Foam lerak tersebut dicampurkan ke dalam mortar sehingga memberikan banyak rongga didalamnya. Pengujian ini beton dengan kadar foam lerak $60 \%$, $70 \%$ dan $80 \%$ dengan perbandingan semen dan kapur 1:4 memiliki nilai kuat tekan saat umur 28 hari sebesar 1,271 $\mathrm{MPa}, 0,543 \mathrm{MPa}$ dan $0,341 \mathrm{MPa}$. Nilai daya serap air $36,34 \%, 43,65 \%$ dan 
60,59\%. Nilai berat jenis $1,149 \mathrm{gr} / \mathrm{cm}^{3}$, Prakoso (2014) tentang mortar ringan dengan material penyusun semen, pasir, air dan foam organik yang dihasilkan dari ekstrak buah lerak menggunakan perbandingan semen dan pasir 1:2, 1:2,5 dan 1,3 akibatnya berat jenis beton menjadi lebih ringan. Sifat fisik dan mekanik dari mortar ringan dengan kadar busa organik 50\% dari volume mortar. Nilai kuat tekan beton dengan fas 0,6 umur 28 hari dengan perbandingan pc: pasir 1:2, 1:2,5 dan 1:3 arti berturut-turut 7,65 $\mathrm{MPa}, 2,81 \mathrm{MPa}, 1,60 \mathrm{MPa}$ sedangkan variasi fas 0,5 dengan perbandingan semen : pasir yaitu 1:2 nilai kuat tekan 4,56 $\mathrm{MPa}$. Nilai daya serap air dengan fas 0,6 yaitu $25,03 \%, 21,83 \%$ dan 19,85 variasi fas 0,5 dengan perbandingan semen : pasir yaitu 1:2 daya serap air $17,44 \%$. Nilai berat jenis dengan fas 0,6 yaitu $1,52 \mathrm{gr} / \mathrm{cm}^{3}, 1,27 \mathrm{gr} / \mathrm{cm}^{3}, 1,18$ $\mathrm{gr} / \mathrm{cm}^{3}$ variasi fas 0,5 dengan perbandingan semen : pasir yaitu 1:2 berat jenis $1,44 \mathrm{gr} / \mathrm{cm}^{3}$.

$$
\text { Megayantha (2013) dalam }
$$
Andriani (2016:21) tentang beton ringan dengan bahan penyusun pasir, semen dan foam organik yang dihasilkan dari ekstrak buah lerak menggunakan perbandingan semen dan pasir 1:1,5. Pengujian ini beton dengan kadar foam lerak $30 \%$ dan $90 \%$ perbandingan semen dan pasir 1:1,5 memiliki nilai kuat tekan saat umur 28 hari sebesar 2,491 $\mathrm{MPa}$ dan 1,371 $\mathrm{MPa}$. Nilai daya serap air $21,60 \%$ dan $27,72 \%$. Nilai berat jenis $1,049 \mathrm{gr} / \mathrm{cm}^{3}$ dan 0,832 $\mathrm{gr} / \mathrm{cm}^{3}$.

Hamad (2014) menjelaskan foam mempunyai kandungan yang baik untuk beton ringan. Hasil pengujian Vian Andriani (2016) menunjukkan bahwa semakin naik kadar foam organik dalam campuran beton maka kuat tekan akan semakin menurun. Berat jenisnya pun juga akan semakin rendah. Untuk nilai daya serap air justru akan semakin
$0,894 \mathrm{gr} / \mathrm{cm}^{3}$ dan $0,879 \mathrm{gr} / \mathrm{cm}^{3}$. besar seiring bertambahnya kadar foam karena kandungan rongga semakin banyak.

Penelitian tentang pemanfaatan busa lerak sebagai bahan pengganti cairan kimia foam agent ADT (Additive Foam Concrete) pada bata beton ringan foam. Selanjutnya pada penelitian ini bertujuan untuk menyelidiki perbedaan kuat tekan, berat jenis dan daya serap air dari bata beton foam dengan kandungan volume busa lerak 30\% dan $40 \%$. Dengan adanya penelitian ini diharapkan dapat menghasilkan kuat tekan bata beton ringan foam yang optimal, sehingga lerak dapat menjadi bahan pengganti cairan kimia foam agent $\mathrm{ADT}$ (Additive Foam Concrete) pada bata beton ringan foam.

\section{METODE PENELITIAN}

Penelitian dilakukan di dua tempat, yaitu untuk pengujian bahan, berat jenis dan daya serap air dilakukan di laboratorium PTB FKIP UNS sedangkan untuk pengujian kuat tekan dilakukan di laboratorium Teknik Sipil UNS. Jenis penelitian yang digunakan pada penelitian ini adalah penelitian kuantitatif eksperimen yaitu dengan mengambil gambaran mengenai perbedaan busa sebagai bahan pengganti cairan foaming agent ADT (Additive Foam Concrete) terhadap kuat tekan, berat jenis dan daya serap air bata beton ringan foam dengan perbandingan campuran 1 semen : 1 pasir dan 1 semen : 2 pasir. Gambaran ini dibuat dengan melakukan eksperimen terhadap sejumlah benda uji untuk mendapatkan data yang dibutuhkan. Menggunakan benda uji silinder dengan diameter $75 \mathrm{~mm}$ dan tinggi $150 \mathrm{~mm}$ pada pengujian kuat tekan sesuai SNI 033421-1994, pengujian berat jenis sesuai SNI-03-1973-1990 dan pengujian daya serap air sesuai SNI-03-0691-1996. Dalam penelitian ini jumlah sampel 
yang digunakan untuk pengujian kuat tekan, berat jenis dan daya serap air bata

beton ringan foam adalah 5 sampel untuk setiap variasinya. Bahan yang digunakan untuk penelitian ini adalah semen Portland tipe I yang digunakan untuk konstruksi umum tanpa memerlukan persyaratan khusus (Tjokrodimuljo,2004), pasir yang memiliki diameter $1 \mathrm{~mm}-5 \mathrm{~mm}$ (Ali Asroni,2010) dan klasifikasi pasir berdasarkan distribusi ukuran butiran sesuai SK-SNI-T-15-1990-03, air yang digunakan sesuai SK-SNI S-04-1989-03 $\mathrm{F}$ dan kadar foam lerak $30 \%$ dan $40 \%$. Teknik pengumpulan data dalam penelitian ini dengan melaksanakan pengujian kuat tekan, berat jenis dan daya serap air bata beton ringan foam. Teknik analisa data yang digunakan adalah T-Test.

\section{HASIL DAN PEMBAHASAN}

\section{Hasil Pengujian Bahan}

Tabel 1. Hasil Pengujian Agregat

\begin{tabular}{llll}
\hline Uji Bahan & Nilai & Standar & Keterangan \\
\hline Kadar lumpur & 4,36 & $<5 \%$ & Memenuhi \\
& $\%$ & & persyaratan \\
\hline Kadar air & $1,3 \%$ & $1-3 \%$ & Memenuhi \\
& & & persyaratan \\
\hline $\begin{array}{l}\text { Kadar } \\
\text { organic }\end{array}$ & $0-10$ & - & Penurunan \\
& $\%$ & & kekuatan \\
\hline $\begin{array}{l}\text { Specific } \\
\text { gravity SSD }\end{array}$ & 2,53 & $2,5-2,7 \%$ & Termasuk \\
& $\%$ & agregat halus \\
& Termasuk & normal \\
\hline Gradasi & daerah II & digunakan \\
\hline
\end{tabular}

Hasil dari serangkaian uji agregat halus (pasir), menyatakan bahwa kadar lumpur memenuhi persyaratan yaitu sebesar $4,36 \%$. Nilai pengujian kadar air memenuhi dari syarat maksimal yaitu $3 \%$. Kadar zat organik mempunyai tingkat penurunan kekuatan 0-10\%. Bulk specific Gravity SSD 2,53 telah memenuhi persyaratan yang ditentukan sesuai SK SNI S-04-1989F.

\section{Pengujian Kuat Tekan Bata Beton Ringan Foam}

Untuk mengetahui perbedaan nilai Thitung kuat tekan bata beton ringan foam dengan persentase penambahan busa lerak 30\% dan $40 \%$ pada campuran 1 semen : 1 pasir dan 1 semen : 2 pasir dapat dilihat pada tabel 2 dan 3 di bawah ini :

Tabel 2. Coefficient Uji T Kuat Tekan 1 semen : 1 pasir

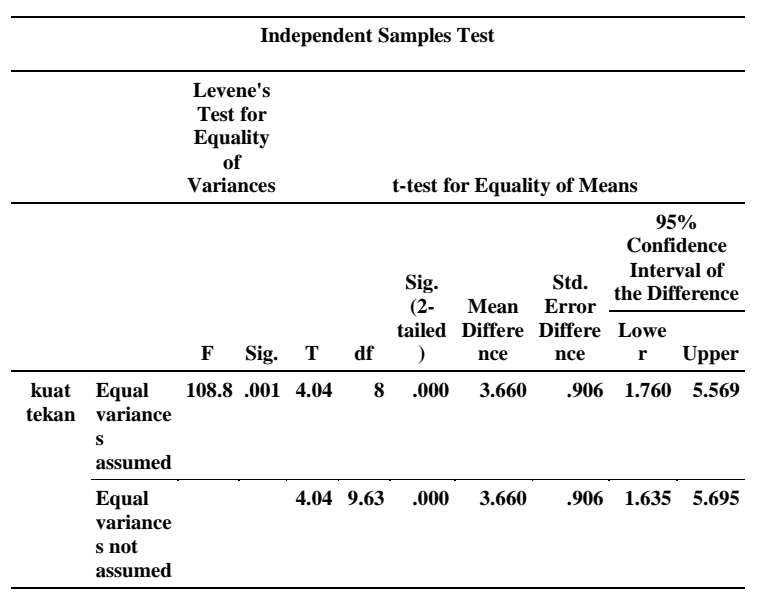

Tabel 2. Coefficient Uji T Kuat Tekan 1semen:1pasir diatas diperoleh nilai THitung sebesar 4,044 dan TTabel sebesar 1,860 diperoleh dari tabel distribusi $t$ untuk taraf signifikansi $5 \%$ dengan nilai df 8 , untuk $t$ tabel dapat dilihat pada lampiran 5 dan untuk probabilitas diperoleh nilai signifikansi sebesar 0,001. Karena THitung > TTabel dan nilai signifikansi $<0,05$, maka $\mathrm{H}_{\mathrm{a}}$ diterima, artinya secara terpisah ada perbedaan antara penggunaan busa lerak dengan perbandingan semen dan pasir terhadap nilai kuat tekan bata beton ringan foam. 
Tabel 3. Coefficient Uji T Kuat Tekan 1

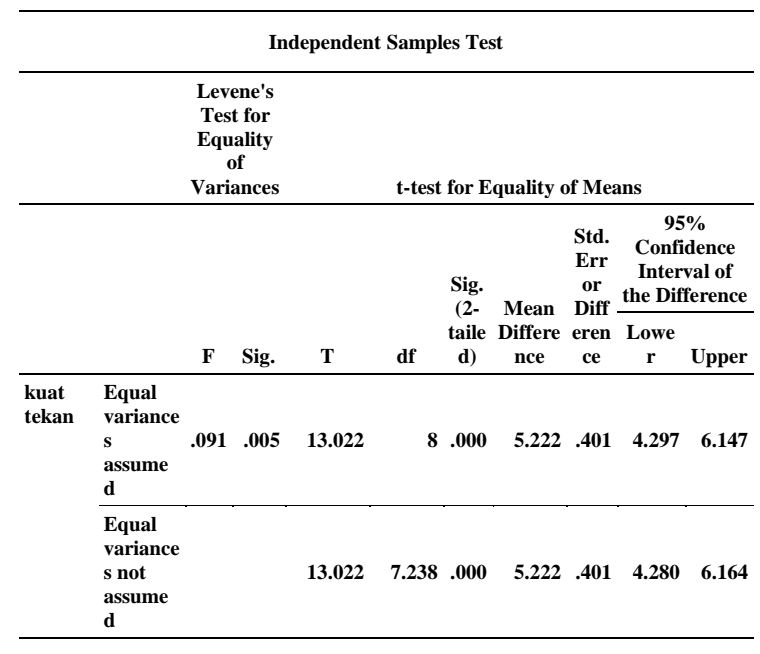

Tabel 3. Coefficient Uji T Kuat Tekan 1semen:2pasir diatas diperoleh nilai THitung sebesar 13,022 dan TTabel sebesar 1,860 diperoleh dari tabel distribusi $t$ untuk taraf signifikansi $5 \%$ dengan nilai df 8 , untuk $t$ tabel dapat dilihat pada lampiran 5 dan untuk probabilitas diperoleh nilai signifikansi sebesar 0,005. Karena THitung > TTabel dan nilai signifikansi $<0,05$, maka $\mathrm{H}_{\mathrm{a}}$ diterima, artinya secara terpisah ada perbedaan antara penggunaan busa lerak dengan perbandingan semen dan pasir terhadap nilai kuat tekan bata beton ringan foam.

Hasil pengujian kuat tekan bata beton ringan foam dengan persentase penambahan busa lerak $30 \%$ dan $40 \%$ pada campuran 1 semen : 1 pasir dan 1 semen : 2 pasir dapat dilihat pada gambar 1 di bawah ini : semen : 2 pasir

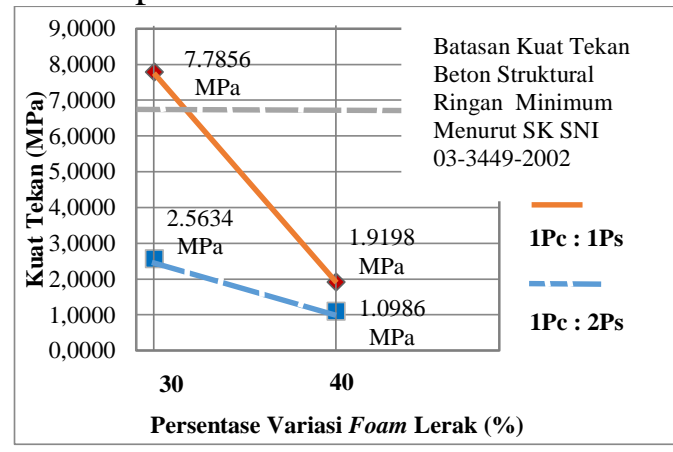

Gambar 1. Grafik Hubungan Variasi Foam Lerak Terhadap Kuat Tekan Bata Beton Ringan Foam

Dari gambar 1 di atas dapat dilihat bahwa terdapat perbedaan nilai kuat tekan bata beton ringan foam dengan variasi persentase busa lerak $30 \%$ dan $40 \%$ pada campuran 1semen:1pasir dengan selisih nilai $5,8658 \mathrm{MPa}$ sedangkan untuk campuran 1semen:2pasir dengan selisih nilai 1,4648 $\mathrm{MPa}$. Pada gambar 1 didapatkan nilai kuat tekan rata-rata bata beton ringan foam pada variasi persentase 30\% lebih besar dibandingkan variasi persentase $40 \%$. Hal ini dikarenakan semakin banyak penambahan foam akan membentuk volume pori-pori dan nilai porositas yang meningkat sehingga benda uji yang dihasilkan memiliki banyak rongga yang membuat benda uji menjadi mudah keropos sehingga memberikan perbedaan penurunan terhadap kekuatan beton (Eko Hindaryanto Nugroho, 2010 dalam Ngarifin, 2015).

\section{Pengujian Berat Jenis Bata Beton Ringan Foam}

Untuk mengetahui perbedaan nilai Thitung berat jenis bata beton ringan foam dengan persentase penambahan busa lerak $30 \%$ dan $40 \%$ pada campuran 1 semen : 1 pasir dan 1 semen : 2 pasir dapat dilihat pada tabel 4 dan 5 di bawah ini : 
Tabel 4. Coefficient Uji T Berat Jenis 1 semen : 1 pasir

\begin{tabular}{|c|c|c|c|c|c|c|c|c|c|c|}
\hline \multicolumn{11}{|c|}{ Independent Samples Test } \\
\hline & & $\begin{array}{c}\text { Leve } \\
\text { Test } \\
\text { Equ } \\
0 \\
\text { Vari }\end{array}$ & $\begin{array}{l}\text { ene's } \\
\text { tor } \\
\text { ality } \\
\text { f } \\
\text { ances }\end{array}$ & \multicolumn{7}{|c|}{ t-test for Equality of Means } \\
\hline & & & & \multirow{2}{*}{\multicolumn{3}{|c|}{$\begin{array}{l}\text { Sig. } \\
\text { (2- } \\
\text { taile } \\
\text { d) }\end{array}$}} & \multirow{2}{*}{$\begin{array}{c}\text { Mean } \\
\text { Differe } \\
\text { nce }\end{array}$} & \multirow{2}{*}{$\begin{array}{c}\text { Std. } \\
\text { Error } \\
\text { Differe } \\
\text { nce }\end{array}$} & \multicolumn{2}{|c|}{$\begin{array}{c}95 \% \\
\text { Confidence } \\
\text { Interval of } \\
\text { the } \\
\text { Difference } \\
\end{array}$} \\
\hline & & $\mathbf{F}$ & Sig. & & & & & & $\begin{array}{c}\text { Lowe } \\
\mathbf{r}\end{array}$ & $\begin{array}{c}\text { Uppe } \\
\text { r }\end{array}$ \\
\hline \multirow[t]{2}{*}{$\begin{array}{l}\text { berat } \\
\text { jenis }\end{array}$} & $\begin{array}{l}\text { Equal } \\
\text { variances } \\
\text { assumed }\end{array}$ & 6.6 & .002 & 8.1 & 8 & .000 & .279 & .034 & .207 & .351 \\
\hline & $\begin{array}{l}\text { Equal } \\
\text { variances } \\
\text { not } \\
\text { assumed }\end{array}$ & & & 8.1 & 17.5 & .000 & .279 & .034 & .207 & .351 \\
\hline
\end{tabular}

Tabel 4. Coefficient Uji T Berat Jenis 1semen:1pasir diatas diperoleh nilai THitung sebesar 8,178 dan TTabel sebesar 1,860 diperoleh dari tabel distribusi $t$ untuk taraf signifikansi $5 \%$ dengan nilai df 8 , untuk $t$ tabel dapat dilihat pada lampiran 5 dan untuk probabilitas diperoleh nilai signifikansi sebesar 0,002. Karena THitung > TTabel dan nilai signifikansi $<0,05$, maka $\mathrm{H}_{\mathrm{a}}$ diterima, artinya secara terpisah ada perbedaan antara penggunaan busa lerak dengan perbandingan semen dan pasir terhadap nilai berat jenis bata beton ringan foam.

Tabel 5. Coefficient Uji T Berat Jenis 1 semen : 2 pasir

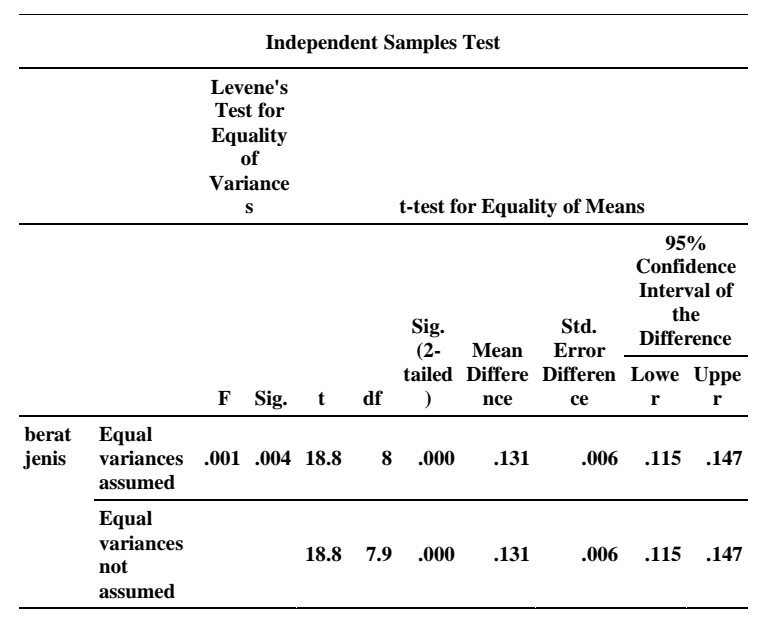

Tabel 5. Coefficient Uji T Berat Jenis 1semen:2pasir diatas diperoleh nilai THitung sebesar 18,898 dan TTabel sebesar 1,860 diperoleh dari tabel distribusi $\mathrm{t}$ untuk taraf signifikansi $5 \%$ dengan nilai df 8 , untuk $t$ tabel dapat dilihat pada lampiran 5 dan untuk probabilitas diperoleh nilai signifikansi sebesar 0,004. Karena THitung > TTabel dan nilai signifikansi $<0,05$, maka $\mathrm{H}_{\mathrm{a}}$ diterima, artinya secara terpisah ada perbedaan antara penggunaan busa lerak dengan perbandingan semen dan pasir terhadap nilai berat jenis bata beton ringan foam.

Hasil pengujian berat jenis bata beton ringan foam dengan persentase penambahan busa lerak $30 \%$ dan $40 \%$ pada campuran 1 semen : 1 pasir dan 1 semen : 2 pasir dapat dilihat pada gambar 2 di bawah ini :

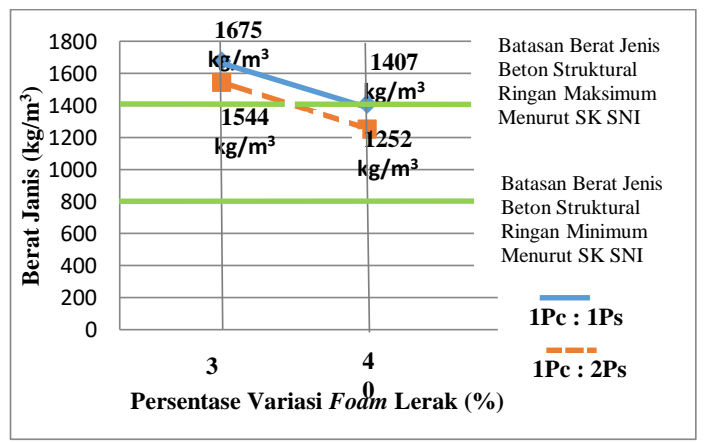

Gambar 2. Grafik Hubungan Variasi Foam Lerak Terhadap Berat Jenis Bata Beton Ringan Foam

Dari gambar 2 di atas dapat dilihat bahwa terdapat perbedaan nilai berat jenis bata beton ringan foam dengan variasi persentase busa lerak $30 \%$ dan $40 \%$ pada campuran 1semen:1pasir dengan selisih nilai $268 \mathrm{~kg} / \mathrm{m}^{3}$ sedangkan untuk campuran 1semen:2pasir dengan selisih nilai $292 \mathrm{~kg} / \mathrm{m}^{3}$. Pada gambar 2 didapatkan nilai berat jenis rata-rata bata beton ringan foam pada variasi persentase $30 \%$ lebih besar 
dibandingkan variasi persentase $40 \%$. Penurunan nilai berat jenis bata beton ringan foam ini dikarenakan semakin sedikit penambahan foam akan menghasilkan nilai porositas dan rongga yang semakin sedikit atau dapat dikatakan bahwa beton ringan tersebut semakin padat dan menyebabkan berat jenis semakin meningkat. (Eko Hindaryanto Nugroho, 2010 dalam Ngarifin, 2015).

\section{Pengujian Daya Serap Air Bata Beton Ringan Foam}

Untuk mengetahui perbedaan nilai Thitung daya serap air bata beton ringan foam dengan persentase penambahan busa lerak 30\% dan $40 \%$ pada campuran 1 semen : 1 pasir dan 1 semen : 2 pasir dapat dilihat pada tabel 6 dan 7 di bawah ini :

Tabel 6. Coefficient Uji T Daya Serap Air 1 semen : 1 pasir

\begin{tabular}{|c|c|c|c|c|c|c|c|c|c|c|}
\hline \multicolumn{11}{|c|}{ Independent Samples Test } \\
\hline & & \multicolumn{3}{|c|}{$\begin{array}{c}\text { Levene's } \\
\text { Test for } \\
\text { Equality of } \\
\text { Variances }\end{array}$} & \multicolumn{6}{|c|}{ t-test for Equality of Means } \\
\hline & & \multirow[b]{2}{*}{$\mathbf{F}$} & \multirow[b]{2}{*}{ Sig. } & \multirow[b]{2}{*}{$\mathbf{T}$} & \multirow[b]{2}{*}{ df } & \multirow{2}{*}{$\begin{array}{c}\text { Sig. } \\
(2- \\
\text { tailed) }\end{array}$} & \multirow{2}{*}{$\begin{array}{c}\text { Mean } \\
\text { Differe } \\
\text { nce }\end{array}$} & \multirow{2}{*}{$\begin{array}{l}\text { Std. } \\
\text { Error } \\
\text { Differ } \\
\text { ence }\end{array}$} & \multicolumn{2}{|c|}{$\begin{array}{c}95 \% \\
\text { Confidence } \\
\text { Interval of } \\
\text { the } \\
\text { Difference }\end{array}$} \\
\hline & & & & & & & & & $\begin{array}{c}\text { Lowe } \\
\mathbf{r}\end{array}$ & Upper \\
\hline \multirow[t]{2}{*}{$\begin{array}{l}\text { daya } \\
\text { serap } \\
\text { air }\end{array}$} & $\begin{array}{l}\text { Equal } \\
\text { variances } \\
\text { assumed }\end{array}$ & 13.8 & .002 & 4.9 & 8 & .000 & 3.762 & .758 & 5.356 & 2.168 \\
\hline & $\begin{array}{l}\text { Equal } \\
\text { variances } \\
\text { not } \\
\text { assumed }\end{array}$ & & & 4.9 & 13.4 & .000 & 3.762 & .758 & 5.396 & 2.128 \\
\hline
\end{tabular}

Tabel 6. Coefficient Uji T Daya Serap Air 1semen:1pasir diatas diperoleh nilai THitung sebesar 4,959 dan TTabel sebesar 1,860 diperoleh dari tabel distribusi $\mathrm{t}$ untuk taraf signifikansi $5 \%$ dengan nilai df 8 , untuk $\mathrm{t}$ tabel dapat dilihat pada lampiran 5 dan untuk probabilitas diperoleh nilai signifikansi sebesar 0,002. Karena THitung $>$ TTabel dan nilai signifikansi $<0,05$, maka $\mathrm{H}_{\mathrm{a}}$ diterima, artinya secara terpisah ada perbedaan antara penggunaan busa lerak dengan perbandingan semen dan pasir terhadap nilai kuat tekan bata beton ringan foam.

Tabel 7. Coefficient Uji T Daya Serap Air 1 semen : 2 pasir

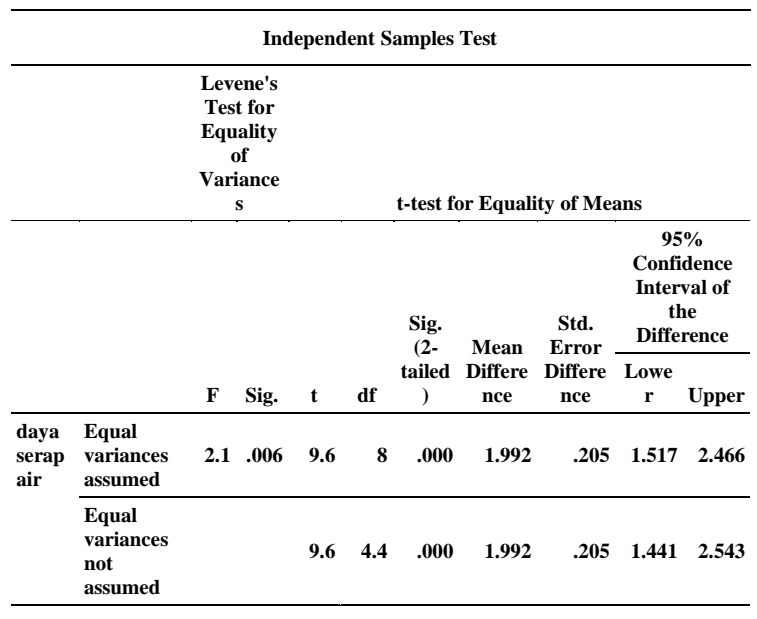

Tabel 7. Coefficient Uji T Daya Serap Air 1semen:2pasir diatas diperoleh nilai THitung sebesar 9,683 dan TTabel sebesar 1,860 diperoleh dari tabel distribusi $\mathrm{t}$ untuk taraf signifikansi $5 \%$ dengan nilai df 8 , untuk $t$ tabel dapat dilihat pada lampiran 5 dan untuk probabilitas diperoleh nilai signifikansi sebesar 0,006. Karena THitung > TTabel dan nilai signifikansi $<0,05$, maka $\mathrm{H}_{\mathrm{a}}$ diterima, artinya secara terpisah ada perbedaan antara penggunaan busa lerak dengan perbandingan semen dan pasir terhadap nilai kuat tekan bata beton ringan foam.

Hasil pengujian daya serap air bata beton ringan foam dengan persentase penambahan busa lerak $30 \%$ dan $40 \%$ pada campuran 1semen:1pasir dan1semen:2pasir 
dapat dilihat pada gambar 3 di bawah ini :

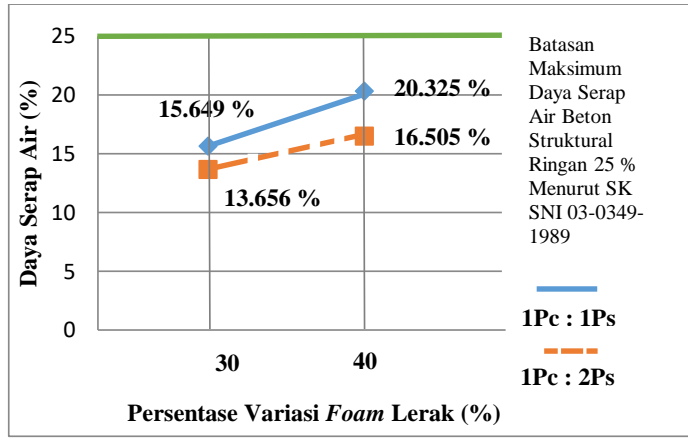

Gambar 3. Grafik Hubungan Variasi

Foam Lerak Terhadap Daya Serap

Air Bata Beton Ringan Foam

Dari gambar 3 di atas dapat dilihat bahwa terdapat perbedaan nilai daya serap air bata beton ringan foam dengan variasi persentase busa lerak $30 \%$ dan $40 \%$ pada campuran 1semen:1pasir dengan selisih nilai $4,676 \%$ sedangkan untuk campuran 1semen:2pasir dengan selisih nilai 2,849\%. Pada gambar 3 didapatkan nilai daya serap air rata-rata bata beton ringan foam pada variasi persentase $40 \%$ lebih besar dibandingkan variasi persentase $30 \%$. Hal ini dikarenakan semakin besar nilai penambahan foam dan butir agregat yang tidak seluruhnya terbungkus mortar, demikian pula halnya ruang antar agregat tidak terisi penuh oleh mortar (Nugraha, Paul, 2007) akibat dari jumlah semen yang lebih sedikit dibandingkan jumlah agregat halus dalam penelitian ini berupa pasir, hal ini berdampak pada terbentuknya pori pori sehingga nilai porositas meningkat yang membuat benda uji menjadi mudah keropos sehingga memberikan perbedaan penurunan terhadap kekuatan beton (Eko Hindaryanto Nugroho, 2010 dalam Ngarifin, 2015) hal tersebut berbanding lurus dengan semakin banyak rongga maka semakin banyak beton menyerap air dan mengakibatkan nilai daya serap air meningkat.

\section{SIMPULAN}

Berdasarkan data hasil penelitian dan pembahasan yang telah dijelaskan pada bab sebelumnya dapat ditarik kesimpulan sebagai berikut :

1. Kuat tekan bata beton ringan foam dengan persentase busa lerak $30 \%$ lebih tinggi dari pada persentase busa lerak $40 \%$, perbedaan kuat tekan pada campuran 1pc:1ps sebesar $5,8658 \mathrm{MPa}(75,34 \%)$ dan pada campuran 1pc:2ps sebesar 1,4648 $\operatorname{Mpa}(57,14 \%)$.

2. Berat jenis bata beton ringan foam dengan persentase busa lerak $30 \%$ lebih tinggi dari pada persentase busa lerak $40 \%$, perbedaan berat jenis pada campuran 1pc:1ps sebesar 268 $\mathrm{kg} / \mathrm{m}^{3}(16 \%)$ dan pada campuran 1pc:2ps sebesar $292 \mathrm{~kg} / \mathrm{m}^{3}(18,91 \%)$.

3. Daya serap air bata beton ringan foam dengan persentase busa lerak $30 \%$ lebih tinggi dari pada persentase busa lerak $40 \%$, perbedaan daya serap air pada campuran 1pc:1ps sebesar 4,676 $\%$ dan pada campuran 1pc:2ps sebesar 2,849\%.

4. Kuat tekan maksimal sebesar 7,7856 Mpa pada busa lerak 30\% perbandingan 1pc:1ps.

\section{SARAN}

1. Perlu dilakukan penelitian lebih lanjut tentang uji kuat tekan, berat jenis dan daya serap air bata beton ringan foam dalam penggunaan busa lerak.

2. Per $\mathrm{m}^{2}$ beton hasil penelitian ini untuk dibandingkan dengan bahan lain. 
DAFTAR PUSTAKA

Andriani, Vian. (2016). Pengaruh Variasi Foam Lerak pada Sifat Fisik dan Mekanik Beton Ringan dengan Perbandingan Campuran Semen dan Kapur 1:4. Sekripsi. Universitas Gadjah Mada. Yogyakarta.

Hamad, A.J. (2014). Materials, Production and Application of Aerated Lightweight Croncret:Rivew. Journal of Materials Science and Engineering.

Khalid. (2011). Mechanical and Physical Properties Of Fly Ash Foamed Concrete. Tesis. Malaysia : Faculty of Civil and Environmental Engineering, University Tun Hussein Onn Malaysia ( UTHM). Khalid. (2011). Mechanical and Physical Properties Of Fly Ash Foamed Concrete. Tesis. Malaysia : Faculty of Civil and Environmental Engineering, University Tun Hussein Onn Malaysia ( UTHM).

Lina, Rosyidah. (2013). Pemanfaatan Lerak. Diperoleh pada 2 Maret 2018, dari https://rosyidahl.wordpress.com/201 3/07/11/18/

Ngarifin. (2015). Pengaruh Penambahan Fly Ash Terhadap Kuat tekan, Berat Jenis dan Daya Hambat Panas Beton Ringan Foam
Sebagai Suplemen Bahan Ajar Mata Kuliah Teknologi Beton Pada Semester III PTB JPTK UNS, Jurnal. Surakarta : $\quad$ FKIP Universitas Sebelas Maret.

Standar Nasional Indonesia. (1990). SNI 03-1973-1990:Metode Pengujian Berat Isi Beton.

Standar Nasional Indonesia. (1994). SNI 15-2049-1994: Semen Portland. Badan Standarisasi Nasional.

Standar Nasional Indonesia. (1994). SNI 03-3421-1994. Cara Uji Kuat Beton Ringan Isolali. Badan standarisasi Nasional.

Standar Nasional Indonesia. (2002). SNI 03-2847-2002. Tata Cara Perhitungan Struktur Beton Untuk Bangunan Gedung. Dewan Standarisasi Nasional.

Tjokrodimoljo, K., (1996), Teknologi Beton. Yogyakarta : Biro Penerbit Keluarga Mahasiswa Teknik Sipil. Universitas Gadjah Mada.

Tjokrodimuljo, K., (2004), Teknologi Bahan Konstruksi, Buku Ajar, Jurusan Teknik Sipil dan Lingkungan Fakultas Teknik, Universitas Gadjah Mada Yogyakarta. 
IJCEE Vol. 5 No.1 Juli 2019, Hal 22-31 